ARCHIVO ESPAÑOL DE ARTE, LXXIX, 316

OCTUBRE-DICIEMBRE, pp. 371-388, 2006

ISSN: 0004-0428

\title{
EL TOLEDO HISTORICISTA, EL PLATERO MAJADAS Y EL BUSTO DE CARLOS V DEL MUSEO DE SANTA CRUZ (TOLEDO)
}

\author{
POR \\ M. José Cuesta García de Leonardo \\ Profesora titular del Departamento de Historia del Arte de la Universidad de Castilla la Mancha
}

Dentro de las elaboraciones historicistas que caracterizan el Toledo de finales del XIX y principios del $\mathrm{XX}$, se observan con peso específico las que aluden a su época imperial, con Carlos V como figura protagonista. Aquí se inserta el busto en plata de este emperador, hoy en el Museo de Santa Cruz de Toledo, atribuido a Leon Leoni. Tal atribución se gesta al tiempo que se iba olvidando la autoría real del platero toledano Majadas, en una operación no totalmente inocente y cuyo punto culminante está en la parafernalia que rodea la exhibición de este busto en la Exposición Internacional de New York, en 1964-65. La técnica, el conocimiento y la sabia utilización, por parte de este orfebre, de la iconografía del XVI y del XVII, con un rico juego de contenidos simbólicos, especialmente elogiosos hacia el Emperador, dan interés a la pieza.

Palabras clave: Toledo, Historicismos, Carlos V, Renacimiento Español, Leone Leoni, Majadas, Plateria, Museo de Sta. Cruz, Exposición Internacional de New York (1964-5).

Within the historicist elaborations characteristic of late 19th and early 20th-century Toledo, Carlos V and his imperial epoch were of great significance. It is here that the bust-length portrait in silver of the Emperor, attributed to Leone Leoni (today in the Museo de la Santa Cruz, Toledo), makes its appearance. This attribution was formed at the same time that its true creator, the Toledan silversmith Majadas, was being forgotten, in an operation that was not entirely innocent and whose culminating moment came with the publicity surrounding its exhibition at the New York World's Fair of 1964-65. The technique utilized by this artisan, his knowledge and use of 16th and 17th-century iconography, and the way he employs a rich play of symbolic content in order to praise the Emperor, all confer special interest on this piece.

Key words: Toledo, Historicism, Carlos V, Spanish Renaissance, Leone Leoni, Majadas, silverwork, Museo de Santa Cru, New York World's Fair.

El Toledo del momento llamado "Fin de Siglo"1 es contemplado por filósofos y literatos contemporáneos como una de las ciudades más evocadoras, dentro de lo que se conoce poéticamente

\footnotetext{
${ }^{1}$ El período llamado "Fin de Siglo" comprende habitualmente desde 1880 a 1914 ó 1918.
} 
con el nombre de las "ciudades muertas" , ciudades sugerentes y transmisoras de sentimientos por la abundancia de testimonios del pasado que las conforman. Los orígenes de estas apreciaciones habría que verlos en la valoración de lo exótico, de lo pintoresco, categorías estéticas de claras vinculaciones románticas. El Regeneracionismo va a aportar a dichas apreciaciones un componente más vivo, dinámico y positivo, de proyección hacia el futuro: esos testimonios del pasado que evidencian sus valores autóctonos, manifiestan -especialmente a través del arte- la esencia de Toledo, como ejemplo culminante de la esencia de Castilla, e incluso, a través de ella, de la propia España; puesto que dichos valores esenciales habrían sido origen de las glorias pasadas, son ahora elementos efectivos a recuperar para intentar la elaboración de un futuro mejor, única garantía para un presente no satisfactorio ${ }^{3}$. Dicha recuperación pondrá el acento en las tradiciones artísticas autóctonas a las que se fomentará con la divulgación de piezas o repertorios iconográficos del pasado, desde museos o exposiciones ${ }^{4}$ : en Toledo, tendrán un protagonismo especial los productos cerámicos, los trabajos en piel, los trabajos en plata, los damasquinados, etc, destacando como objetos característicos, las armas y las armaduras. De esta forma asistimos a la legitimación teórica de los "revivals", en el seno de las recuperaciones historicistas que caracterizan muchas elaboraciones artísticas de la época. Y el siglo XVI alcanza protagonismo en el conjunto de las mismas: Carlos V es el máximo referente del esplendor de la historia de España y especialmente de Toledo, el Toledo Imperial. Por eso, el siglo XVI pervive en el estilo de las elaboraciones toledanas, evocando dichas glorias, contrapunto esperanzador en momentos de crisis -habría que recordar el desastre del 98 y los distintos movimientos de protesta social, de finales del anterior y principios del nuevo siglo-. A la vez, en el conjunto de las evocaciones del siglo XVI, el referente iconográfico común para muchas de las artes mencionadas, es el grutesco en sus múltiples y fantásticas posibilidades 5 .

De esta forma pasamos a abordar el busto en plata de Carlos V, hoy en el museo de Santa Cruz de Toledo $^{6}$ (Figs. 1 y 2). Tiene una delicada elaboración orfebre y, probablemente por su cabeza, llegó a atribuirse a León Leoni ${ }^{7}$. Sin embargo, parece suficientemente probado por C. Heredia Moreno y A. López - Yarto Elizalde que su autor es un platero toledano de ese fin de siglo, apellidado Majadas ${ }^{8}$. El modelo que sirvió de referencia es el busto en bronce del Emperador, hecho

\footnotetext{
2 Para estos aspectos ver N. Campos, J. Herrero: Ciudades y paisajes de la Mancha vistos por viajeros románticos (Ciudad Real y Toledo). Diputación de Ciudad Real. Biblioteca de autores y temas manchegos. Ciudad Real, 1994.

${ }^{3}$ Defendiendo a estos planteamientos podemos ver a Unamuno, Ganivet, A. Machado, Azorín, Ortega y Gasset y a las teorías de Krausismo, difundido en España en estos momentos a través de la Institución Libre de Enseñanza. Es interesante destacar cómo esta Institución -especialmente bajo la dirección de Ginér de los Ríos- se interesa por la valoración de lo técnico y su enseñanza, rompiendo la separación jerárquica tradicional entre Bellas Artes y Artes Mecánicas: el trabajo técnico como modo de desarrollar las artes tradicionales y autóctonas que, en el caso de Toledo, enlaza, por ejemplo, con sus elaboraciones en plata.

${ }^{4}$ Ver F. González Moreno: Decadencia y Revival en la azulejería talaverana. Retablos, altares y paneles del "Renacimiento Ruiz de Luna". Edit. Ayuntamiento de Talavera de la Reina. Toledo, 2002.

5 Por ejemplo, para la cerámica, ver: F. González Moreno: Decadencia ... op. cit; o para los damasquinados de los Zuloaga, de gran influencia en los toledanos, ver: J. D. Lavin: El arte y la tradición de los Zuloaga. Damasquinado español de la colección Khalili. Patronato de la Alhambra y Generalife. Consejería de Cultura de la Junta de Andalucía. Bilbao, 2000. Es interesante observar cómo tanto para muchas obras de damasquinado, de las últimas décadas del siglo XIX, de los Zuloaga, como para el busto de Carlos V, en plata, que ahora nos ocupa, los referentes iconográficos están en series de grutescos o en piezas del siglo XVI, hoy en la Armería Nacional, en especial en rodelas y borgoñotas del taller de los Negroli, elaboradas para Carlos V.

${ }^{6}$ Majadas: Busto retrato del Emperador Carlos V. Fines del siglo XIX - primeros del siglo XX. Técnica: orfebrería en plata. Alt.- 0,92 metros; Anch.- 0,58 metros; Prof.- 0,34 metros. Museo de Santa Cruz. Toledo. Número de inventario general: 1817 .

${ }^{7}$ No hay ninguna fuente que confirme esta atribución ni que haga proceder del siglo XVI a esta pieza.

${ }^{8}$ Efectivamente, el sello de Majadas aparece en la parte superior del espaldar y en el borde inferior trasero de la peana. El sello con su nombre se acompaña de otro, con un águila bicéfala, a la derecha, y otro sello con letras mayúsculas
} 
por ambos Leoni, fechado en Milán, en torno a 1553, del Museo del Prado9. La cabeza es una copia, quizás, incluso contemporánea, del mismo ${ }^{10}$ : la configuración del cabello le acerca al modelo clásico y su rostro refleja serenidad, distanciamiento, majestad, traduciendo, en un gesto, fórmulas que se fueron codificando para plasmar de manera idónea la imagen, no sólo de Carlos -como persona concreta y, por tanto, identificable- sino la del propio poder imperial que él encarna ${ }^{11}$. Ambos bustos llevan el Toisón con su cadena de eslabones y pedernales centelleantes. La armadura, con peto, espaldar y hombreras ${ }^{12}$, sigue en ambos un tipo de decoración en bandas verticales, flanqueadas por pequeñas formas triangulares, recordando la armadura que Carlos llevó en Mühlberg y asimilando las connotaciones triunfales de la misma ${ }^{13}$. Distinguiéndose del milanés, el busto del Museo de Santa Cruz se apoya en una peana de sección octogonal y cuenta con una decoración mucho más abundante y sobresaliente que se extiende, tanto en la peana, como, especialmente, en las franjas verticales mencionadas y en las hombreras, a diferencia de una mayor sencillez en la figura de los Leoni. Por esta exuberancia decorativa y por la forma de distribución de la misma, la referencia es la "armadura de parada" de Felipe II, hecha por A. Pffenhauser, que también conocería Majadas ${ }^{14}$.

Este tipo de retrato de Carlos a la romana ${ }^{15}$, que comienza a aparecer en la iconografía carolina a partir de su propia coronación como Emperador en Bolonia, en 1530, y de la victoria de Túnez, en 1535, por propia decisión del Emperador ${ }^{16}$, es el que mejor evocó su carácter imperial.

de la palabra Toledo, a la izquierda (Fig.3). Sobre la identificación de la autoría, ver: C. Heredia Moreno, A. López-Yarto Elizalde: "Los triunfos del Emperador en las artes del metal", El arte en las cortes de Carlos V y Felipe II, C.S.I.C., Madrid, 1999, pág 363-375. Estas autoras ubican a Majadas en torno a 1900.

${ }^{9}$ Leone y Pompeo Leoni. Busto de Carlos V, h. 1553. Bronce. Altura 112 centímetros. Madrid. Museo Nacional del Prado.

10 C. Heredia Moreno y A. López-Yarto Elizalde dejan abierta la posibilidad de que la cabeza sea "quizás un vaciado antiguo" de la mencionada de los Leoni. Porque, continúan, "conviene recordar que León Leoni realizó una serie de retratos reales en plata para la reina María de Hungría, a imitación de la proyectada para Carlos V, que fueron terminados en España por su hijo Pompeyo en tiempos de Felipe II ... la cabeza quizás pudiera ser un vaciado antiguo aprovechado en la obra de Majadas". Op. cit, pág 374.

${ }^{11}$ F. Checa: Carlos V. La imagen del poder en el Renacimiento. Ediciones El Viso. Madrid, 1999.

12 Las "incorrecciones en la forma y disposición en las hombreras" -como señalan C. Heredia Moreno y A. Gómez-Yarto Elizalde, op. cit, pág 374-, son un motivo más que nos alejan de la atribución a los Leoni. La interpretación de los eslabones y pedernales de la cadena del Toisón, de forma excesivamente floreada, inciden en lo mismo. Y otro motivo que aleja de la consideración de los Leoni como autores del busto es la decisión tomada por el propio Carlos $\mathrm{V}$ en 1531, a propósito de la decoración de sus armaduras: "todos los petos ostentan la imagen de Nuestra Señora y los espaldares, la de Santa Bárbara, distintivos que siempre llevaron las corazas del Emperador desde el 1531 en adelante" (Conde Viudo de Valencia de Don Juan. Catálogo Histórico-descriptivo de la Real Armería de Madrid. Madrid, 1898. Ed facsímil de Librerías París-Valencia, S. L. Valencia, 2000. Pág 61); y este tipo de decoración es algo que, como veremos, no se tiene en cuenta en la iconografía desarrollada en la armadura que nos ocupa y que, los Leoni, sí hubieran respetado.

${ }^{13}$ El tipo de decoración llamado Mühlberg evoca la armadura llevada por Carlos en la batalla de este nombre -el 24 de abril de 1547; en ella venció a los príncipes protestantes alemanes, con importantes implicaciones en lo religioso y en lo político para su gobierno-. De esta forma se asimila a dicha armadura toda una serie de implicaciones de carácter áulico y por ello es la armadura que eligen distintos autores -quizás con la indicación del propio Carlos- para representarle en todo su esplendor: es la elegida por el propio Tiziano para su retrato ecuestre "Carlos V en Mühlberg" (1548. Madrid, Museo del Prado); o por los Leoni, no sólo en el busto en bronce al que nos hemos referido, sino también para su escultura de cuerpo entero, en mármol, "El Emperador Carlos V" (hecha entre 1553-1554, Madrid, Museo del Prado).

14 Armadura catalogada como A.290 en la Real Armería del Palacio Real de Madrid. A. Pffenhauser, armero de Augsburgo, la elaboró en torno a 1560. A. Soler del Campo. Guía Real Armería. Palacio Real. Patrimonio Nacional, Madrid, 2000. Pág. 70.

$15 \mathrm{La}$ forma del busto con armadura alude a la manera utilizada para retratarse, con gran componente áulico, de los emperadores romanos; de forma específica, al busto de los Leoni, modelo del nuestro, se le relaciona, a su vez, con otro modelo, el busto de Cómodo del Museo Capitolino de Roma.

${ }^{16}$ F. Checa. Carlos V y la imagen del héroe en el Renacimiento. Edit. Taurus, Madrid,1987; F. Checa. Carlos V. La imagen del poder en el Renacimiento. Ediciones El Viso, Madrid. 1999. 


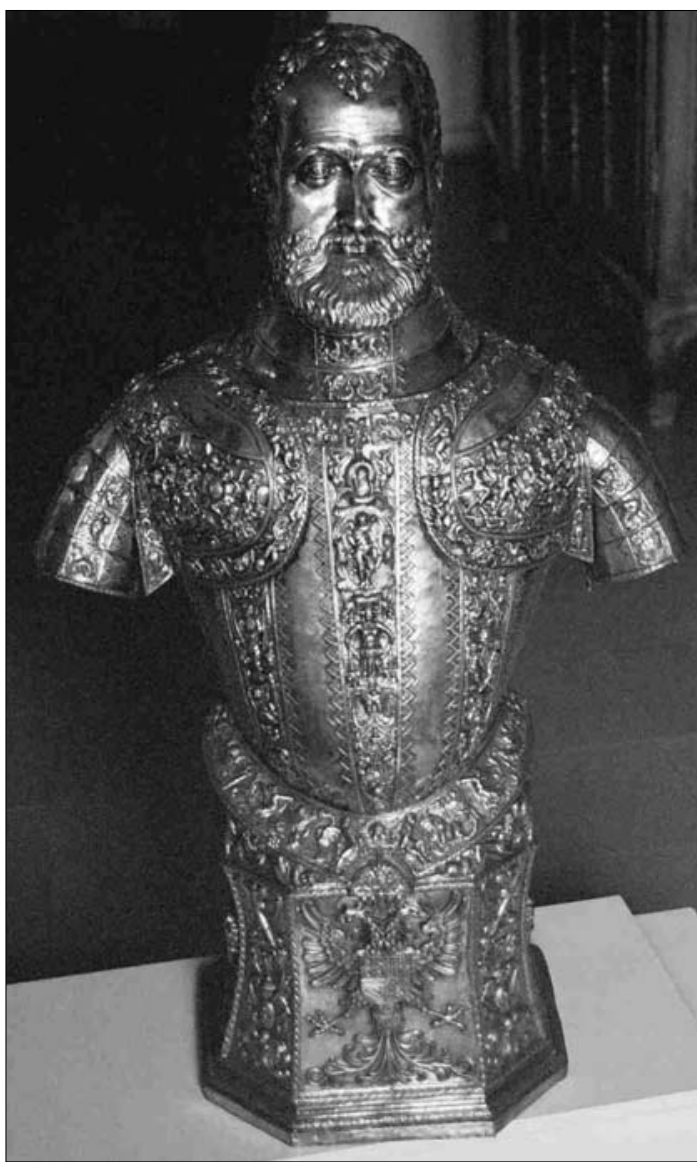

Figura 1. Busto retrato del Emperador Carlos V. Museo de Santa Cruz. Toledo. Parte delantera.

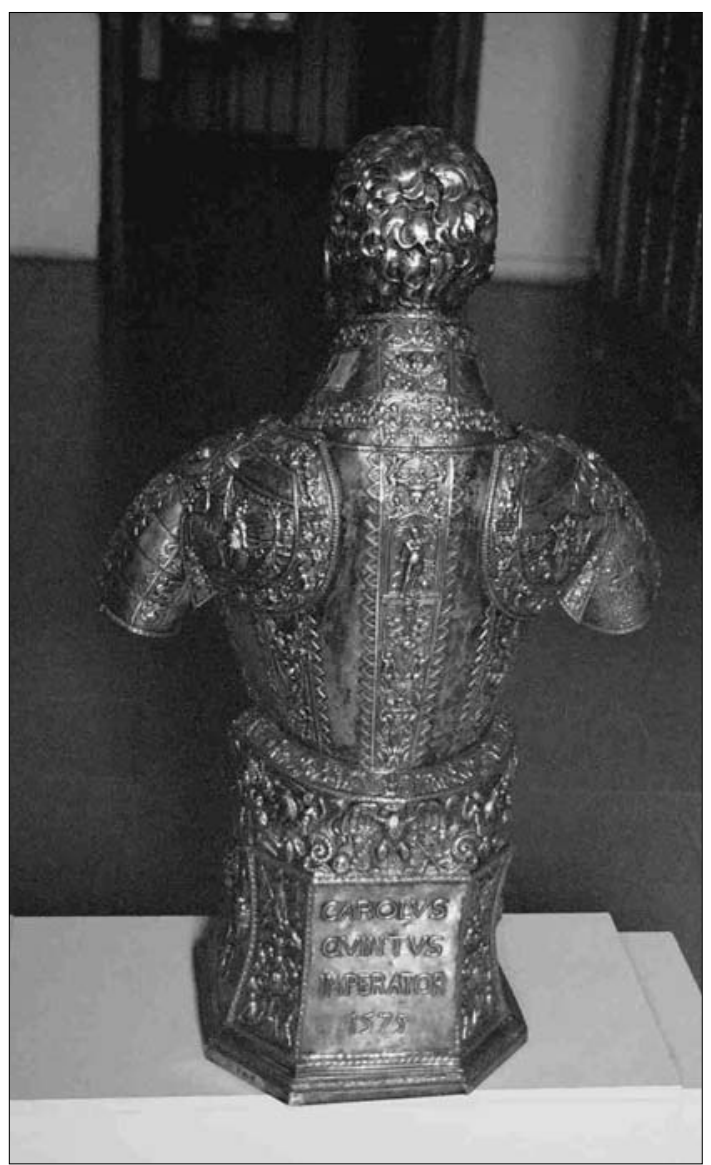

Figura 2. Busto retrato del Emperador Carlos V. Museo De Santa Cruz. Toledo. Parte trasera.

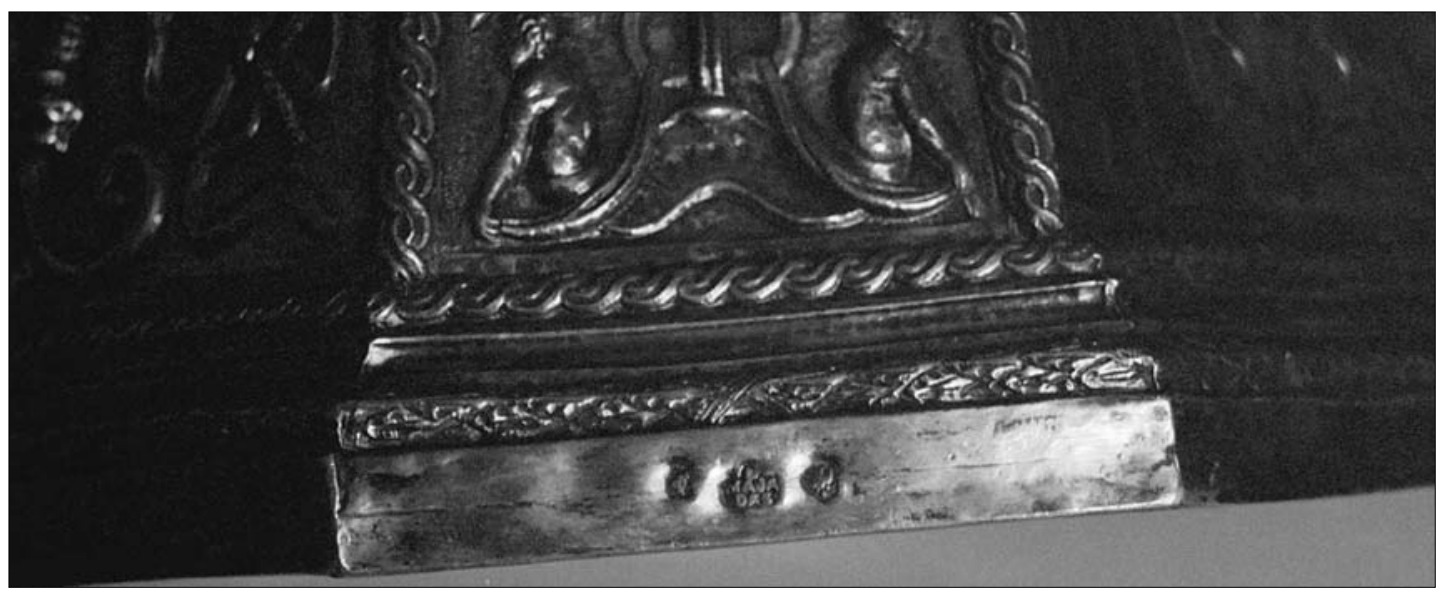

Figura 3. Parte inferior de la peana donde se observan los tres marcas. 
Y Majadas le añade un repertorio iconográfico idóneo al mismo: en la parte delantera de las hombreras (Figs. 4 y 5), la referencia iconográfica principal será el relieve de la borgoñota de Carlos V, del taller milanés de los Negroli, armeros del Emperador ${ }^{17}$ (Fig. 6): en la hombrera derecha de Carlos se representa una escena de combate entre romanos y cartagineses, teniendo al fondo, en un monte, las murallas de Cartago y, en primer plano, el enfrentamiento de dos jinetes, rodeados de otros soldados, algunos en el suelo. La muralla del fondo y los dos jinetes enfrentados son copia casi exacta de dicha borgoñota, concretamente de su lado derecho. Aquí, igual que en la hombrera, entre los jinetes y a los pies de los caballos, hay un soldado caído protegiéndose con un escudo; pero el soldado de la hombrera no copia al de la borgoñota sino a otro, en semejante circunstancia, a los pies del jinete central, en la rodela que hace juego con la borgoñota ${ }^{18}$ (Fig 7): es una figura muy curiosa porque gira de manera muy forzada el torso para protegerse la cabeza con su escudo. Hay que señalar cómo uno de los jinetes enfrentados nos muestra un escudo, con una cabeza monstruosa en su centro -aunque no es la de la Medusa, la podría recordar19-, que se intenta reproducir también en la hombrera de Carlos, en el mismo jinete. El resto de los personajes y los de la hombrera izquierda (que continúan el mismo combate, con la misma ciudad amurallada al fondo) también encuentran, en este juego de rodela y borgoñota del taller de los Negroli, su inspiración. Así, el soldado que está de pié, en el centro de la hombrera izquierda, con un jinete a cada lado, con escudo ovalado y gran casco con penacho, girando con fuerza el torso y levantando el brazo derecho con su espada para dar un golpe con ella, es muy semejante a otro soldado de la rodela, aunque éste segundo no se vea de cuerpo entero por tener delante un jinete caído, al que va a golpear. También es interesante observar cómo el detalle de un escudo decorado con un gran rostro, éste sí evocador de la Medusa, que aparece en el suelo, en un extremo de la rodela, se ve también caído y en el mismo extremo, pero ahora con un gran rostro masculino barbado, en la hombrera izquierda de Carlos. Si la calidad de los relieves de las citadas rodela y borgoñota milanesas, en sus anatomías, en sus expresiones ... es conocida, la calidad de los relieves de Majadas, y no sólo en los copiados más fielmente, también lo es: la anatomía vigorosa y detallada en hombres y caballos, el movimiento y la expresión de los rostros, la perfección del pequeño detalle, nos dan la altura de su maestría. Con estos relieves se alude a la identificación simbólica -evidentemente, áulica y frecuente en su momento, sobre todo a partir de la Victoria de Túnez- entre Carlos y el héroe romano Escipión. Las escenas de las dos hombreras están enmarcadas, al modo de cartelas, teniendo cada una, en su extremo exterior y por fuera de la línea sobresaliente que las delimita, una cabeza alada de cuya boca sale una cinta que se engancha en dicha línea: son querubines voladores que estarían prestos a difundir las glorias del Emperador o las de los héroes que le simbolizan; en las hombreras de la espalda se usa el mismo recurso iconográfico.

La lectura de la parte delantera continúa con el collar de la Orden del Toisón: desde la fundación de la misma por Felipe el Bueno en 1429, se elabora una compleja unión simbólica del Jasón griego en la conquista del vellocino de oro -símbolo de Jerusalén, que debe ser reconquistado-, con el Gedeón bíblico - para quien el vellón es el símbolo del apoyo de Dios frente a los

17 Esta borgoñota está catalogada como D3, en la Real Armería del Palacio Real de Madrid. El detalle iconográfico está señalado por C. Heredia Moreno, A. López-Yarto Elizalde: “Los triunfos del Emperador ...”. Op. cit, pág 372-374; añaden estas autoras cómo, tanto la borgoñota como la rodela del juego, "presentan escenas de batallas entre romanos y cartagineses inspiradas en la 'Historia de Roma' de Tito Livio que fue, a su vez, la probable fuente de inspiración para la serie grabada por Marco Antonio Raimondi para Francisco I en 1535, según pinturas de Julio Romano, o para la de Tobías Stimmer. Algunos de estos grabados ... se copian de forma casi literal ...”.

18 Esta rodela está catalogada como D-4. Real Armería del Palacio Real de Madrid.

19 Quizás sea interesante recordar la rodela con la cabeza de la Medusa de los propios Negroli (Rodela de parada de Carlos V, llamada de la Medusa. Milán, 1541. Real Armería del Palacio Real de Madrid, D-64) o la rodela de Filippo Negroli con la cabeza de león ( Rodela de parada de Carlos V, Milán, 1533.Real Armería del Palacio Real de Madrid, D-2). 
Figura 4. Hombrera delantera derecha.

Figura 5. Hombrera delantera izquierda.

Figura 6. Borgoñota milanesa del taller de los Negroli (lado derecho). Real Armería. Foto Copyright () Patrimonio Nacional. Madrid.
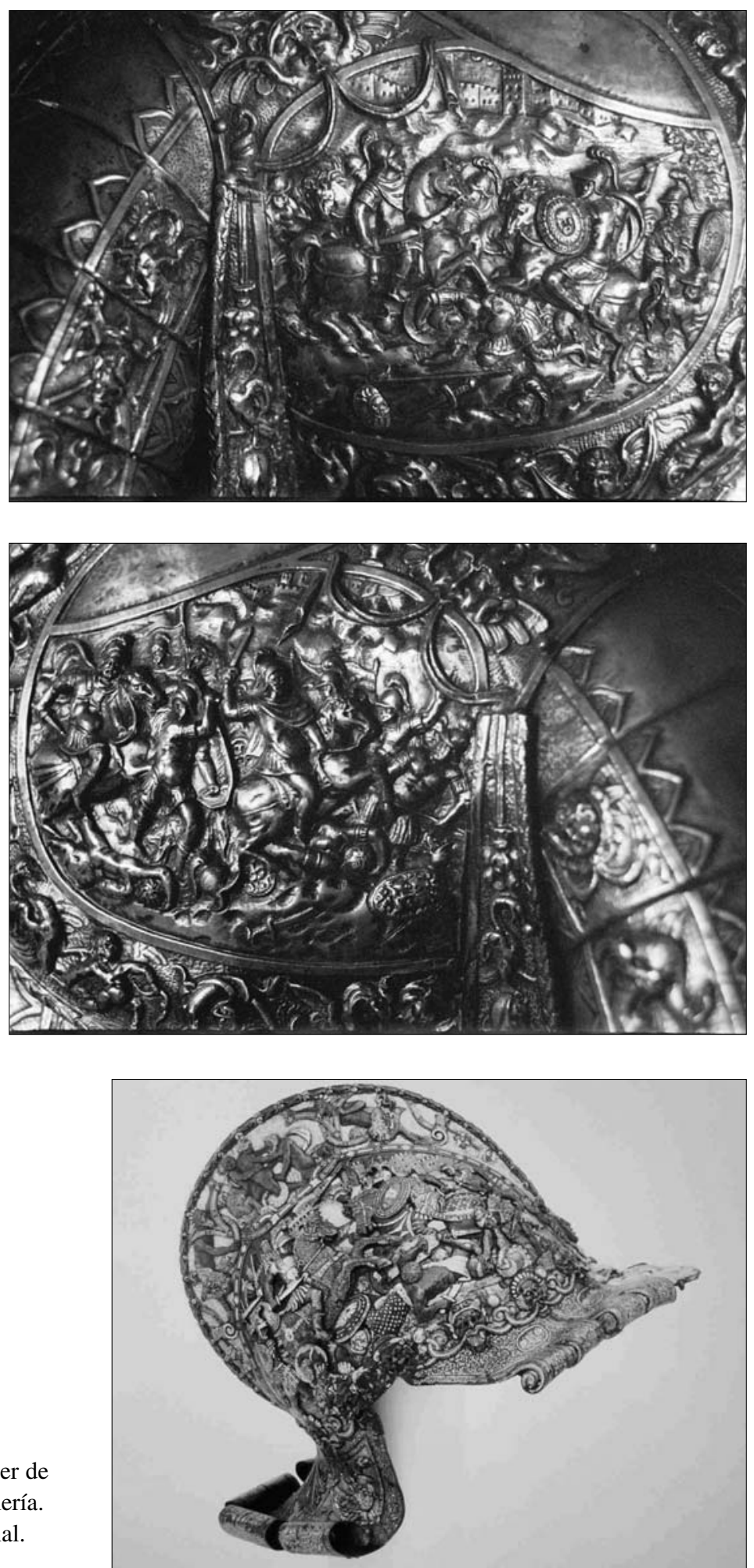
madianitas idólatras-; debajo de esta metáfora se señala un objetivo caballeresco de lucha contra el infiel -lucha que también incluirá, más tarde, a los protestantes-. Carlos V dio mucha importancia a su pertenencia a dicha Orden; el collar, compuesto por eslabones y pedernales centelleantes que se alternan y que sostienen al vellocino, es casi emblema del propio Carlos - con todo el simbolismo caballeresco de gran vitalidad en la época ${ }^{20}$-, y también de la monarquía española e incluso del escudo de la ciudad de Toledo, el Toledo Imperial. Y, a la lucha de Escipión, el héroe de la Antigüedad, dicho Toisón añade el acento cristiano.

El Toisón está flanqueado por dos dragones alados. Aunque se les puede asociar a la manifestación de la vigilancia, generalmente, encarnan el poder del mal y son vencidos, entre otros héroes, por Perseo, S. Jorge o S. Miguel. Aquí, jugando quizás con los dos significados, acentúan el poder del Toisón al que sirven.

Debajo del mismo, iniciando la decoración de la franja vertical central -la cual está flanqueada por otras dos pequeñas bandas que nacen debajo de las hombreras-, se sitúa la imagen de un Cupido en una cartela ovalada, en la zona donde habitualmente se colocan imágenes de Cristo o de la Virgen ${ }^{21}$ (Fig. 8): Majadas desconoce la preferencia de Carlos por colocar imágenes de vírgenes en la cartela central del peto, en este caso, en dicha franja. Por eso pone este Cupido, con sus alas, su carcaj, flechas y arco, con los ojos descubiertos; en este sentido, interesa recordar como, frente al Amor Profano que aparece con los ojos vendados, el Amor Sacro no lleva ven$\mathrm{da}^{22}$, en una iconografía suficientemente popular y conocida con probabilidad por Majadas, con lo que podemos observar, aunque de otra forma, una incidencia en los mismos aspectos de carácter religioso, considerados de especial importancia para el buen gobierno.

Debajo de la cartela de Cupido, aparece una figura femenina como término, a modo de Demeter, diosa de la agricultura, con alusiones a la fecundidad y a la abundancia: su cabeza lleva una corona con cuernos de vaca y está enmarcada por gavillas de cereales que penden de la parte baja de la cartela de Cupido; de sus brazos y enganchados con largos velos que bajan de la parte trasera de su cabeza, grandes manojos de frutas ${ }^{23}$. Es la abundancia prometida como resultado del buen gobierno basado en la verdadera religión.

La decoración de esta franja vertical continua con elementos de tipo grutesco hasta el final de la misma, donde aparece significativamente la cabeza de un león que se asocia, simbólicamente, a la monarquía española; sobre dicha cabeza, sostenidos por un lienzo, rodelas y borgoñotas a modo de trofeos militares; debajo de ella y ya en la "faldilla" con que termina la coraza en la cintura, se coloca la cabeza de Medusa. Esta otra cabeza también tiene un contenido simbólico interesante por su alusión a Perseo, quien la habría cortado protegido por la diosa Atenea: alusión metafórica a la victoria sobre el mal que alude al propio Carlos, de una forma áulica. La cabeza de Medusa está encima de la corona imperial que aparece sostenida por el águila bicéfala con el escudo, constituyendo la decoración de la parte frontal de la peana ${ }^{24}$.

En la espalda, en las hombreras, se reproduce el mismo fondo de ciudad amurallada vista en las de delante; pero, frente al abigarramiento de personajes de las hombreras anteriores, ahora sólo hay una figura femenina en cada una: en la hombrera izquierda de Carlos (Fig. 10) se representa

${ }^{20}$ F. Checa. Carlos V y la imagen del héroe en el Renacimiento. Edit. Taurus ,Madrid, 1987; F. Checa. Carlos V. La imagen del poder en el Renacimiento. Ediciones El Viso, Madrid, 1999.

21 Ver la nota número 12.

22 Ver E. Panofsky: Estudios de Iconología. Alianza, Madrid, 1976.

23 J.F.M. Noël Diccionario de la Mitología Universal. Edicomunicación, s.a., Barcelona, 1987. (1801, “Dictionnaire Universel de la Fable et de la Mythologie"); P. Grimal: Diccionario de Mitología Griega y Romana. Ed Paidos. Barcelona, 1984; J. L. Morales y Marín: Diccionario de Iconología y Simbología. Ed Taurus, Madrid, 1984.

${ }^{24}$ Basta añadir a dicha águila coronada el collar del Toisón para que reproduzca el escudo de la propia ciudad de Toledo que, como se sabe, es el de Carlos V. 
Figura 8. Parte superior delantera de la armadura.

Figura 7. Rodela milanesa del taller de los Negroli. Real Armería. Foto Copyright () Patrimonio Nacional. Madrid.
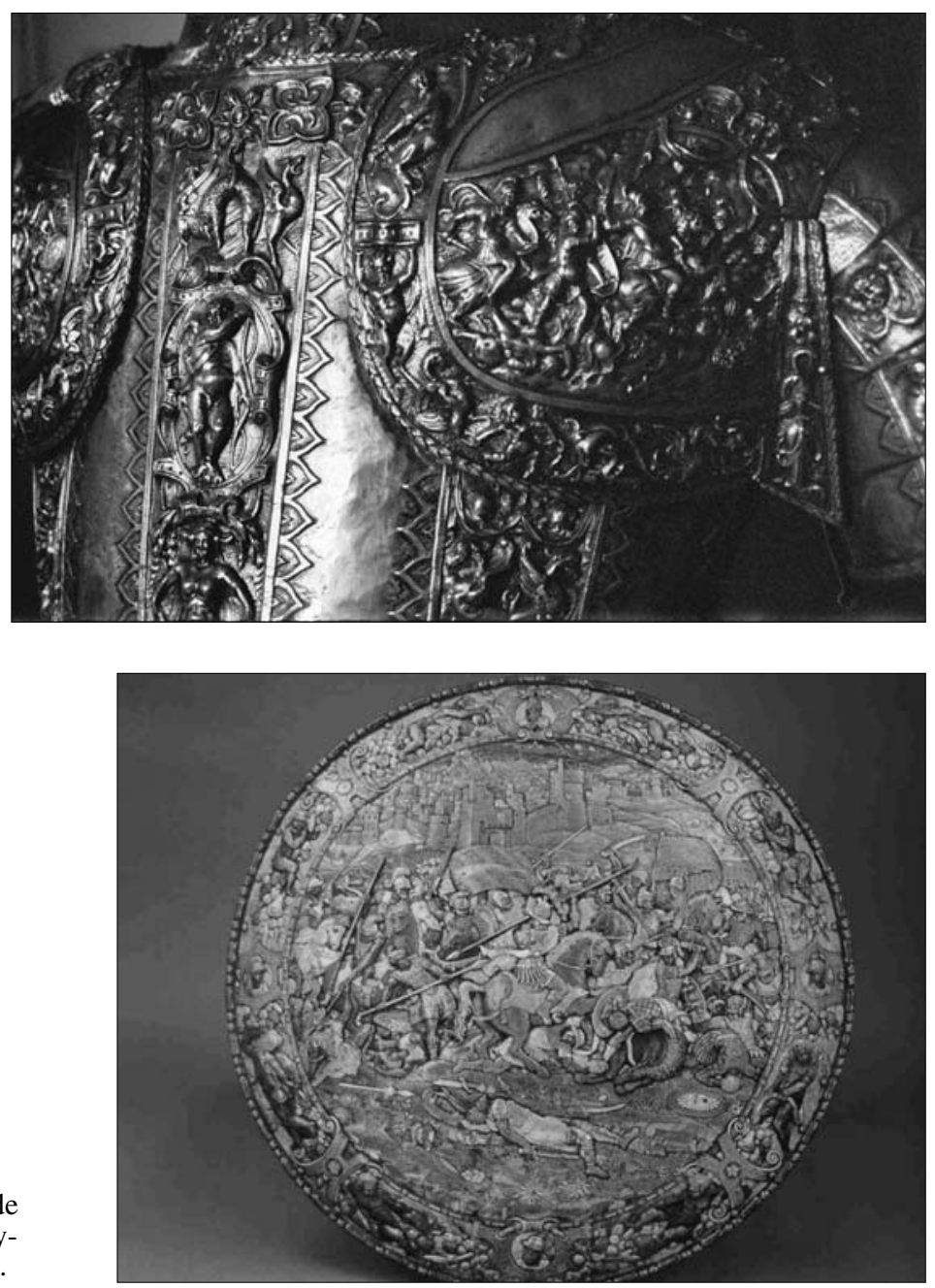

Figura 9. Hombrera trasera derecha.

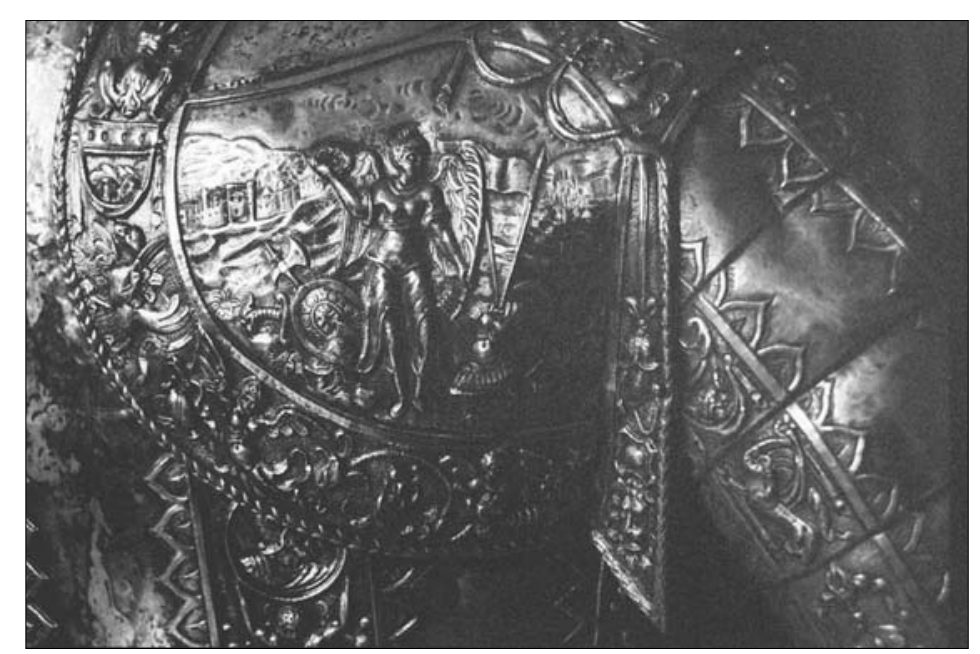

AEA, LXXIX, 316, OCTUBRE-DICIEMBRE, 371-388, 2006, ISSN: 0004-0428 
a Atenea con un gran casco con penacho, que sujeta con su derecha una lanza y, con su izquierda, apoya en el suelo un gran escudo, con una forma saliente por su parte superior y terminado en un óvalo apuntado en la inferior, el cual tiene en su centro la cabeza de la Medusa. En todo lo descrito, esta figura se asemeja a la Atenea del emblema XXII de Alciato, "Custodiendas Virgines", de la primera edición en castellano -Lyon, 1548-1549 25 - (Fig. 11). Se diferencia en el giro de la piernas y en cómo, la Atenea de la hombrera, pisa con su pie derecho un casco enemigo. Detrás, más armas enemigas en un montón, al pie de un árbol, probablemente un olivo; este árbol se asocia a Atenea, quien primeramente lo cultivó e inventó el aceite. Es un árbol evocador de la nueva era de paz, gracias a la victoria sobre los enemigos. Atenea es una diosa guerrera pero también lo es de la razón, de las ciencias, de la filosofía y de las artes, por lo que su patrocinio significa el apoyo y el fomento de las mismas, en beneficio de la nación; es protectora de guerreros esforzados y valientes, de Jasón y de Perseo en sus heróicas luchas contra los monstruos, siempre símbolos del mal. Recordemos cómo ambos héroes se vinculan metafóricamente a Carlos: Jasón, desde su relación mítica con la Orden del Toisón, prefiguración del propio Carlos, y Perseo en su lucha contra los seres monstruosos. Así, Atenea es también diosa protectora de Carlos, nuevo héroe defensor de la cristiandad. Por eso, la imagen de la hombrera derecha de Carlos es la alegoría de la Victoria (Fig. 9): joven alada que, pisando las armas de los enemigos derrotados, está a punto de volar para llevar la corona de laurel, que sostiene con su derecha, y la palma del triunfo y de la fama, que sujeta con su izquierda, a Carlos, el nuevo héroe.

En el centro, en la decoración de la franja vertical, como en el interior de una hornacina cuya repisa sostuviera un querubín, se dispone otra figura femenina, repartiendo un ramo de frutos, junto a una corneja que está erguida a sus pies: así se alude a la piedad, a la liberalidad y a la concor$\operatorname{dia}^{26}$ (Fig. 12). A la liberalidad también se asocia el león, cuya cabeza coronada -como símbolo de buen rey- aparece en la parte superior de la hornacina. Piedad, liberalidad y concordia son virtudes de un buen gobierno, propiciadas por el buen rey, en alusión general al gobierno de Carlos.

La banda continúa con elementos decorativos de tipo grutesco hasta llegar a los que se disponen en sentido horizontal, en la zona que se extiende entre el busto y la peana. Aquí (Fig. 15), la decoración que corresponde a la parte posterior de la peana, consiste en los atributos de la monarquía española: el águila centrando el espacio, detrás el león, jugando con el globo terráqueo que aparece a un lado del águila, a su derecha, y a su izquierda, las columnas del Plus Ultra entre las que se enrolla una orla y una rama de laurel, prometedora de la fama inmortal para sus triunfos. Y ahora se nos descubre la ironía de Majadas: si una de estas columnas está entera, aunque a punto de caerse, la otra está ya rota, en dos trozos, lo que recordaría la empresa, sin número, de mote "Ludibria Mortis", de D. Saavedra Fajardo 27 (Fig. 16), donde las columnas, rotas y caídas por el suelo, son una evocación tipo "vanitas", que recuerda como terminan en nada las glorias humanas, algo que, de un modo sutil, sirve a Majadas para enlazar esas glorias del pasado con su bastante menos glorioso momento presente. Habría que añadir que, si esta es la decoración de la franja superior a la peana, en el flanco trasero de ésta, justo debajo de la decoración vista, aparece esta inscripción: "CAROLUS QUINTUS IMPERATOR 1575". Teniendo en cuenta que la muerte de Carlos se produjo en 1558 y que esta fecha de $1575^{28}$, sin que sea relevante en el desarrollo

\footnotetext{
25 Alciato. Emblemas. Editora Nacional, Madrid, 1975, (1548-49), pág. 96.

26 C. Ripa. Iconología. Edit. Akal, Madrid, 1987, (1603).

27 D. Saavedra Fajardo. Empresas Políticas. Idea de un príncipe político cristiano. Editora Nacional, Madrid, 1976, (1640), pág. 933.

28 Para jugar más con los números, podemos recordar que, justo en 1557, es decir, cambiando los dos últimos números con respecto al de la peana, fue la victoria de Felipe II en San Quintín. Pero sin duda, la inscripción de este año en nuestra pieza, es uno de los posibles orígenes de los errores de atribución, como veremos en los distintos textos que tratan de la obra. Por otra parte, en 1575 Felipe II se está planteando el modelo de enterramiento que cristalizará en la década de los 80, cuando comiencen los Leoni a hacer los grupos escultóricos funerarios de El Escorial.
} 


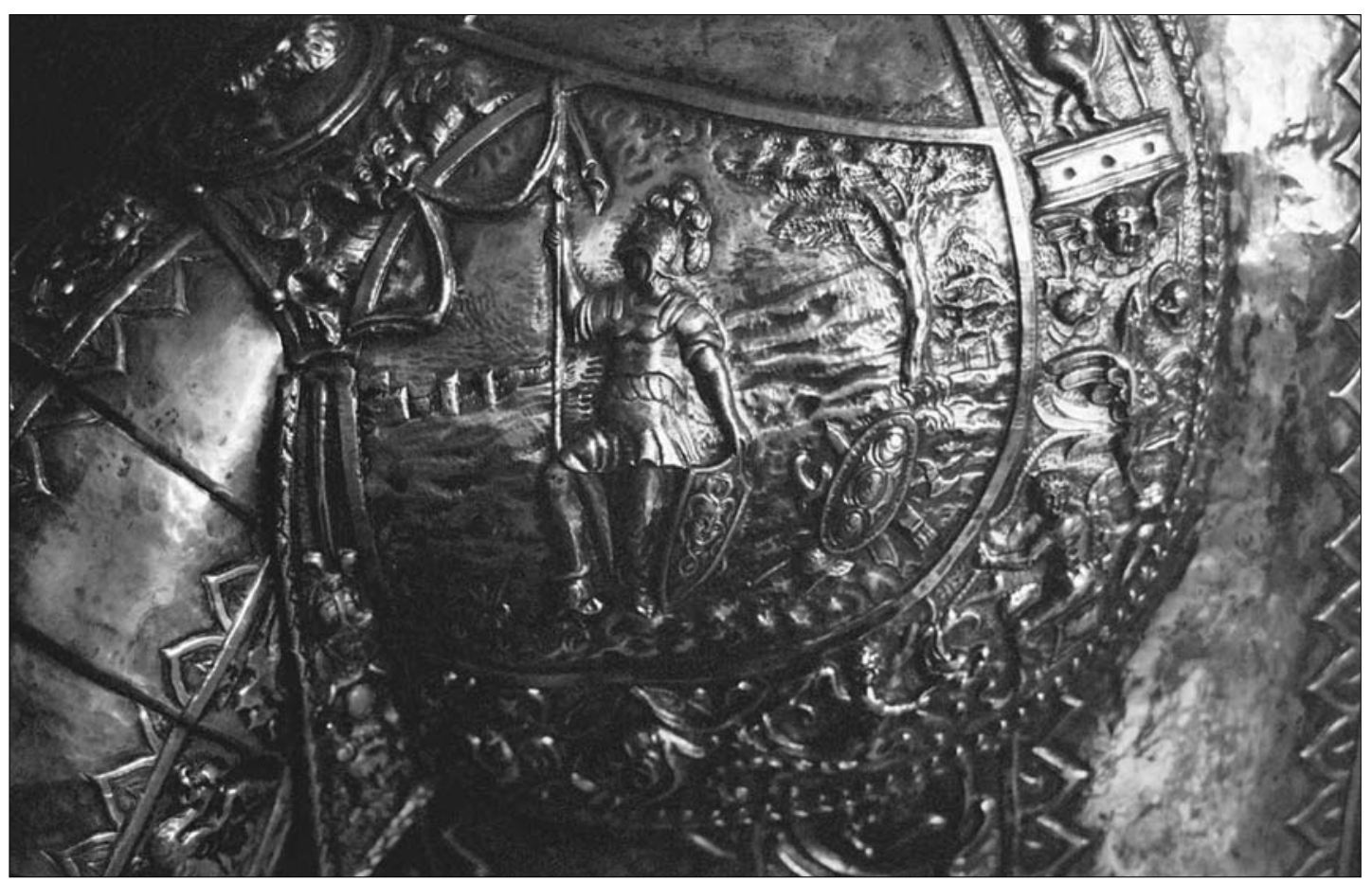

Figura 10. Hombrera trasera izquierda. Atenea.

Figura 11. Alciato. Emblema XXII. "Que las doncellas han de ser muy guardadas". (Reproducción de: Alciato. Emblemas. Editora Nacional. Madrid, 1975, pag. 96.)

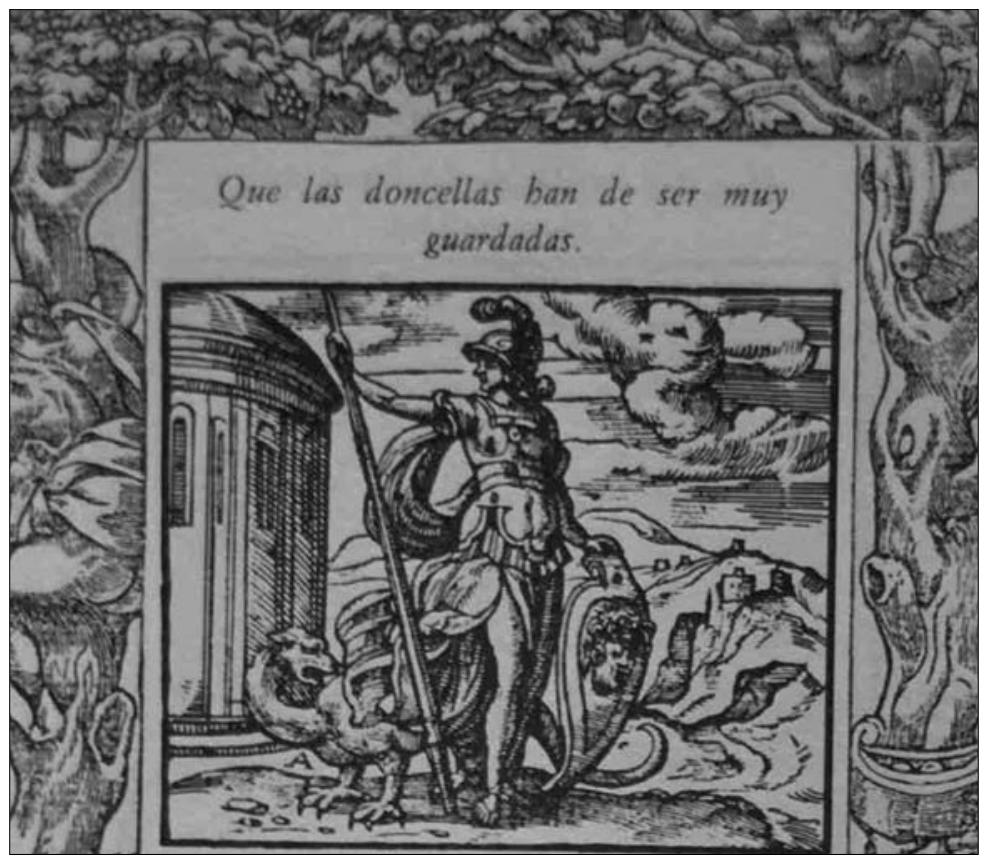

AEA, LXXIX, 316, OCTUBRE-DICIEMBRE, 371-388, 2006, ISSN: 0004-0428 


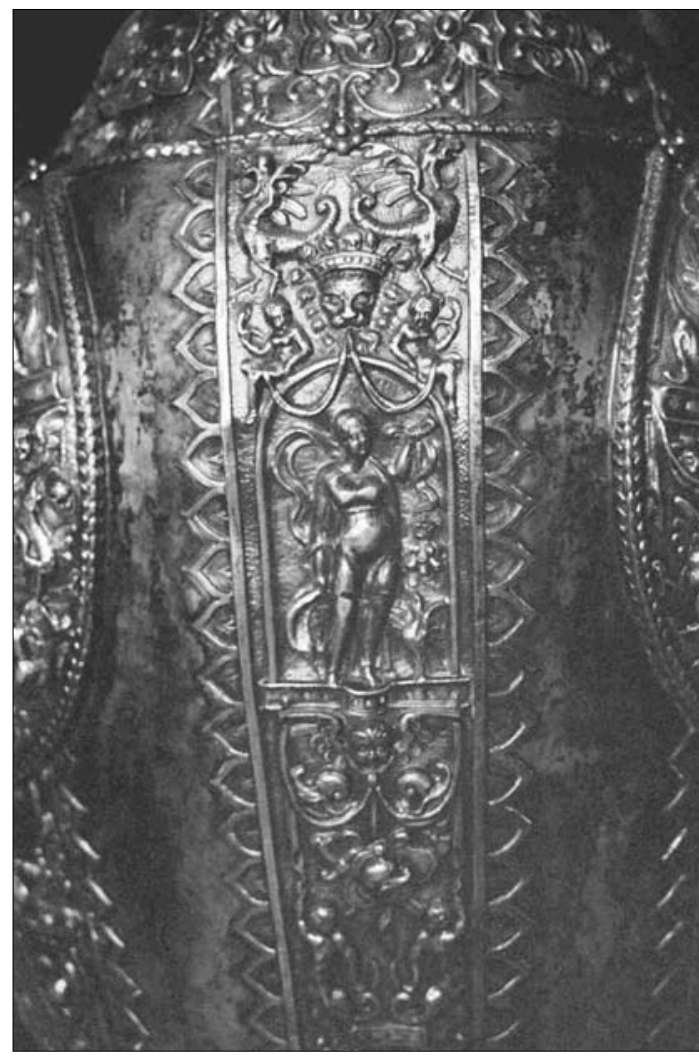

Figura 12. Franja central trasera.

de la obra de los Leoni, corresponde, sin embargo, al año de la segunda bancarrota de Felipe II, podría ser de nuevo un guiño irónico de Majadas, enlazando así con la propia contemporaneidad.

En los dos laterales anchos de la peana se repiten los símbolos del poder imperial (espada, cetro, corona imperial) con la empresa carolina del Plus Ultra: las columnas sostienen la corona imperial y en ellas se enreda la cinta con la inscripción; entre dichas columnas, el mar; flanqueándolas a ellas y a la corona, dos grandes cornucopias llenas de frutos, promesa de fertilidad y abundancia, palmas y ramas de laurel, augurando triunfos y fama inmortal (Fig. 13). La forma en que se disponen estas cornucopias - divergentes, a modo de gran $\mathrm{Y}$ - recuerda a las que utiliza Alciato en su emblema CXVIII (Fig. 14), "Virtute Fortuna Comes" -primera edición en castellano, Lyon, 1548-1549-: donde aquí vemos al emblema de Carlos, al Plus Ultra y a la corona imperial, Alciato pone el caduceo, el gorro alado de Mercurio y dos serpientes, en alusión a "los elocuentes / Varones de equidad muy escogida, / Dotada de consejos muy prudentes", a los que "Fortuna les abonda / Y en lo que responder es bien responda" 29 . De esta forma Carlos, ecuánime y prudente, será digno de la protección de la Fortuna. El cetro y la espada, atados con un elegante lazo, se encuentran repetidos en las dos esquinas inferiores.

Los retratos que siguen el modelo de las monedas de la Antigüedad, son algo que rápidamente alude al mundo clásico y, por ello, de gran uso en el XVI ; nuestro busto también los tiene: en la

${ }^{29}$ Alciato. Emblemas. Editora Nacional, Madrid, 1975, (1548-49), pág 71. 


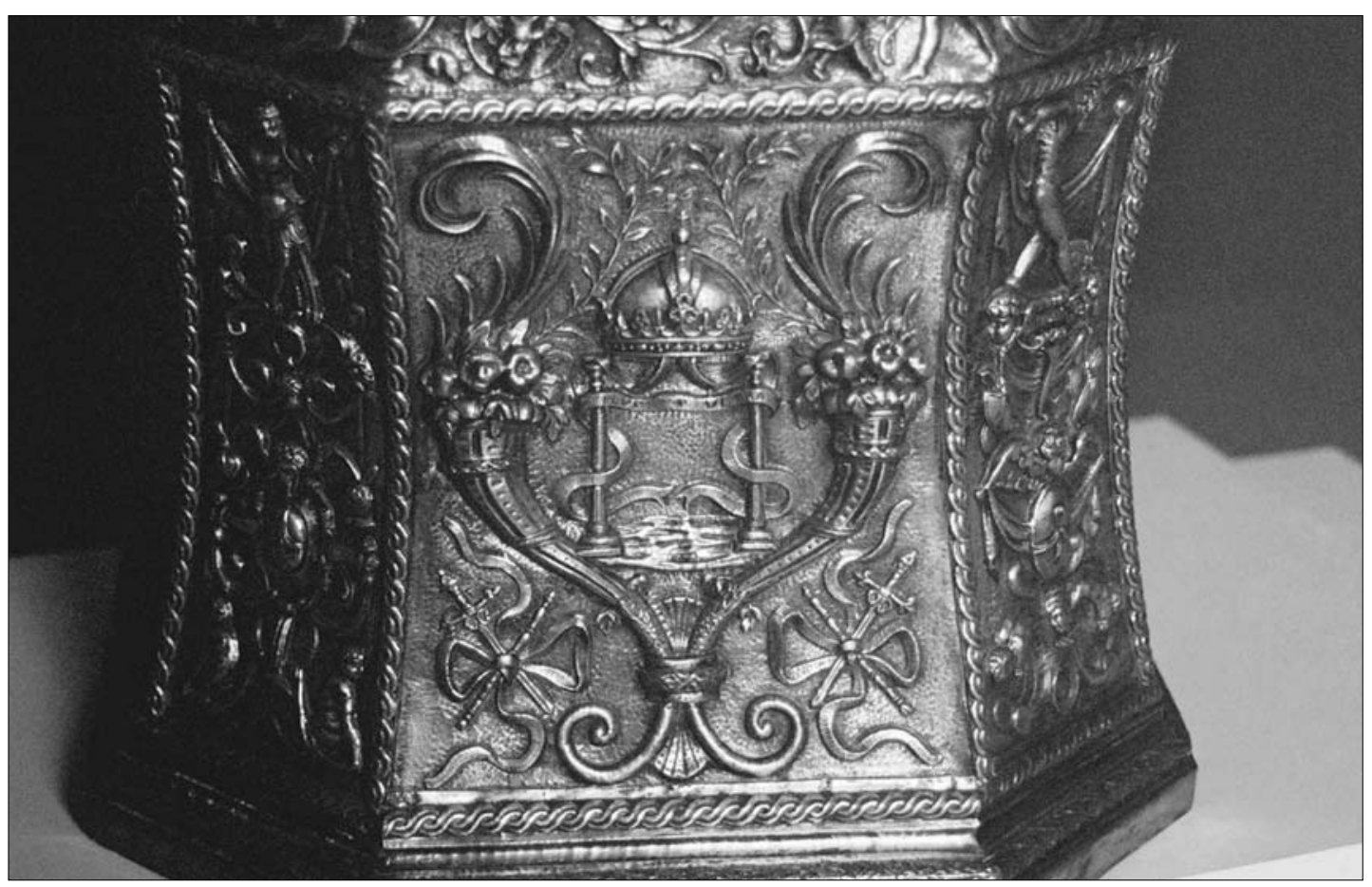

Figura 13. Lateral ancho de la peana.

Figura 14. Alciato. Emblema CXVIII. "Que la Fortuna sigue a la Virtud". Editora Nacional. Madrid,1975, pag. 71).

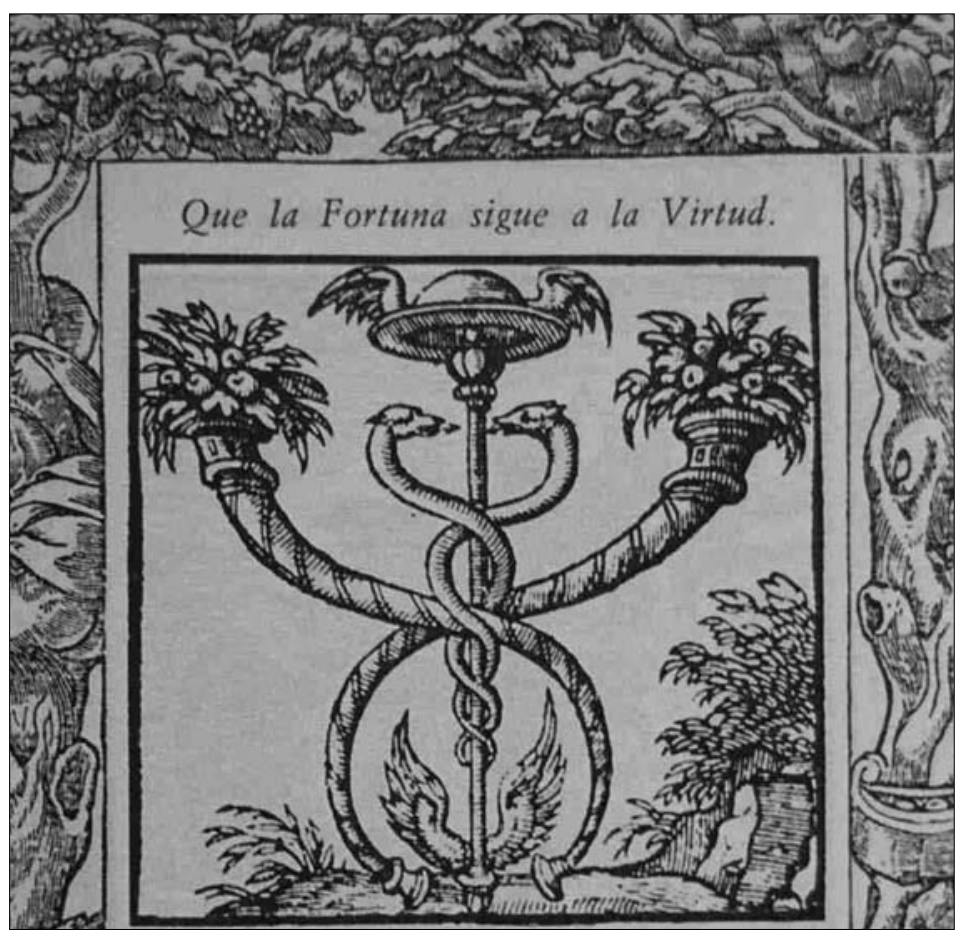

AEA, LXXIX, 316, OCTUBRE-DICIEMBRE, 371-388, 2006, ISSN: 0004-0428 
parte superior de las mangas, a la altura del hombro; al comienzo de las dos franjas verticales de los lados de la espalda (aquí, medio tapadas por la estructura superpuesta de las hombreras); y al comienzo de las dos franjas verticales de debajo del principio de la manga. Son medallones circulares, al modo de monedas, donde Majadas lleva a cabo delicados retratos de personajes a la manera antigua, de perfil, todos distintos salvo los dos de los hombros, que son iguales y están de tres cuartos. De ellos, sólo el que está debajo de la hombrera con la representación de la Victoria, es un soldado maduro, barbado, con casco y coraza; el que está enfrente de éste, debajo de Atenea, es también un personaje barbado, quizás anciano, de perfil, pero no va armado. Los de encima de los hombros representan a un hombre maduro y barbado, quizás un filósofo. Y los de debajo de las mangas, son personas jóvenes, imberbes, uno -a la izquierda de Carlos- tocado con un elegante gorro con una pluma y el otro -a la derecha de Carlos-, quizá una mujer, sujetando con una cinta su largo cabello. Siendo imposible la identificación de estos personajes, en todo caso su objetivo es reforzar el referente clásico que se quiere lograr con el conjunto.

El resto de la decoración -en las cenefas que encuadran las hombreras; a lo largo de las franjas verticales que recorren la armadura (una a cada lado de las centrales, tanto en el peto como en el espaldar; otras dos, saliendo cada una de debajo de la manga; y tres más en cada manga); en la franja horizontal de apoyo en la peana, en los ocho lados de ésta ...- es absolutamente variada y de gran perfección en el mínimo detalle. Reproduce una iconografía de grutescos con animales y personajes fantásticos, a veces enfrentados, frutos, máscaras, putti, querubines, lazos, cartelas, grifos, dragones, centauros, faunos, trofeos militares, formas vegetales... y entre ellos, abundantes alusiones marinas con personajes portadores de tridentes -en su mayoría niños-, tritones, caballos de mar, e incluso ancianos barbados y recostados, a los que, sin embargo, les falta la vasija surtidora de agua. Este tipo de referencias hablarían siempre de las victorias de Carlos frente al mal, frente a todo tipo de infieles y, de una forma concreta, de la expansión del imperio carolino a través de los mares, de sus victorias marítimas, así como también de la abundancia que se sigue de todo ello (Fig. 17 y 18).

Esta iconografía se relaciona con repertorios de grutescos, en ocasiones con fórmulas que recuerdan a los grabados del texto de Colonna, Sueño de Polifilo ${ }^{30}$. En uno de los laterales -el izquierdo-, en la faldilla de la coraza, podemos ver una calavera alada, sostenida por un lienzo, a modo de "vanitas", recogiendo una forma tradicional de representar el paso del tiempo y la prontitud de la muerte y apareciendo -de forma camuflada- en un contexto completamente ajeno: su significación no será tanto vinculable a ese contexto, como a una reflexión muy oportuna del propio Majadas que nos da, incluso, su punto de vista con relación al pasado. El mismo motivo del lienzo se repite en dicha franja de la faldilla y transporta querubines o borgoñotas y rodelas, a modo de triunfo. Es interesante señalar como la calavera mencionada coincide con un niño vestido, portador de un arco, que levanta su brazo izquierdo y el correspondiente dedo corazón en parecida forma de higa, en un conocido gesto de desprecio, mirando a una escena de enfrentamiento entre seres monstruosos en la que participan otros niños y que preside una figura femenina, portadora de armas a modo de triunfos bélicos, evocadora de la Victoria. El niño es retirado y va siendo recriminado, a causa de su gesto, por un anciano. Esta escena se repite a ambos lados de la franja que enlaza con la peana, a los lados del águila, león y columnas mencionadas aunque en el otro lado, el niño no mira a la escena del enfrentamiento. ¿Podríamos hablar de la ironía de Majadas en la contemplación de las glorias pasadas?.¿Podrían ser los Nuevos Tiempos -en la figura del niño- criticando la vacía grandilocuencia de los Antiguos en un momento de desmoronamiento, vinculable a la crisis de 1898 ?

\footnotetext{
30 Ver en la edición de Pilar Pedraza, F. Colonna, Sueño de Polifilo. Ed Comisión de Cultura del Colegio Oficial de Aparejadores y Arquitectos Técnicos de Murcia. Murcia, 1981.
} 
Figura 15. Parte inferior trasero de la armadura y lado trasero de la peana.

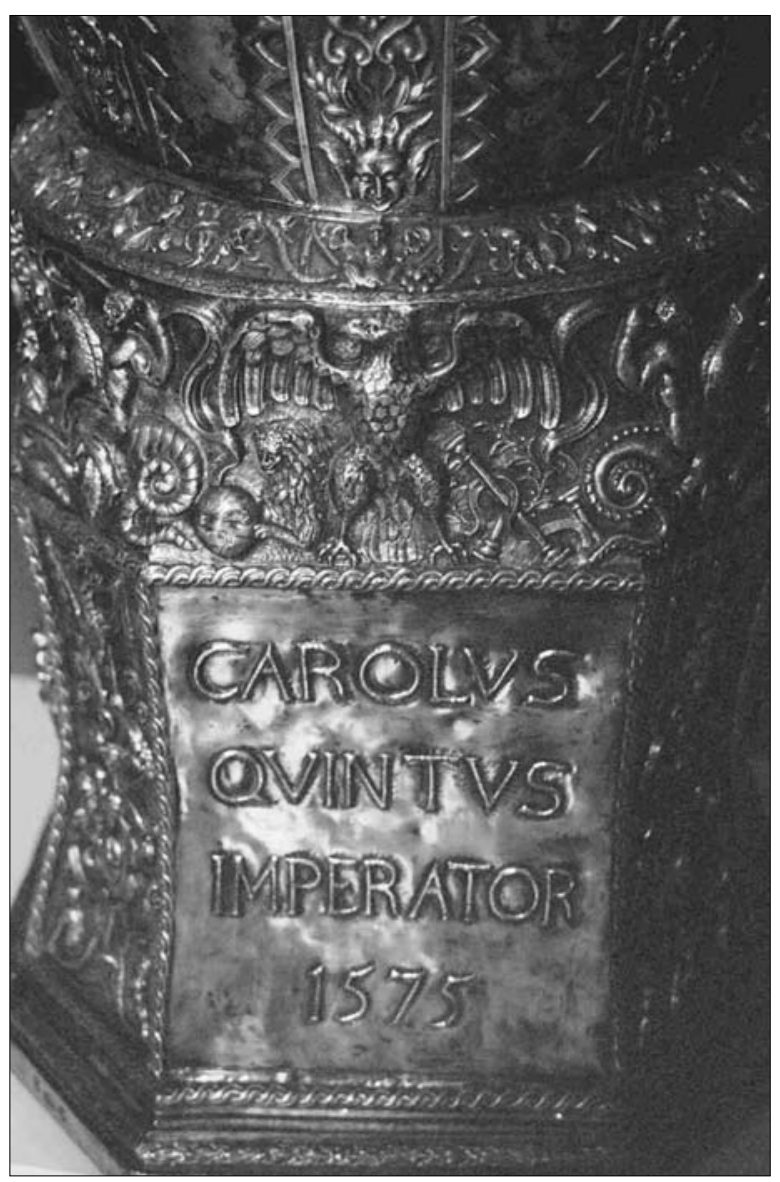

Figura 16. D. Saavedra Fajardo. Empresa: "Ludibria Mortis".

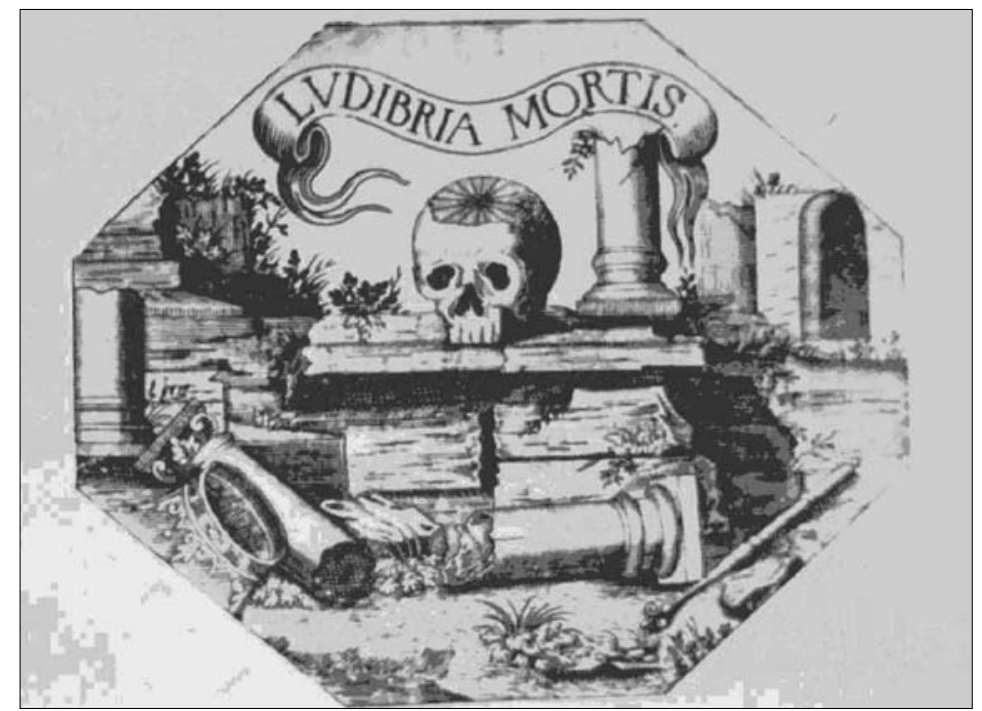

AEA, LXXIX, 316, OCTUBRE-DICIEMBRE, 371-388, 2006, ISSN: 0004-0428 


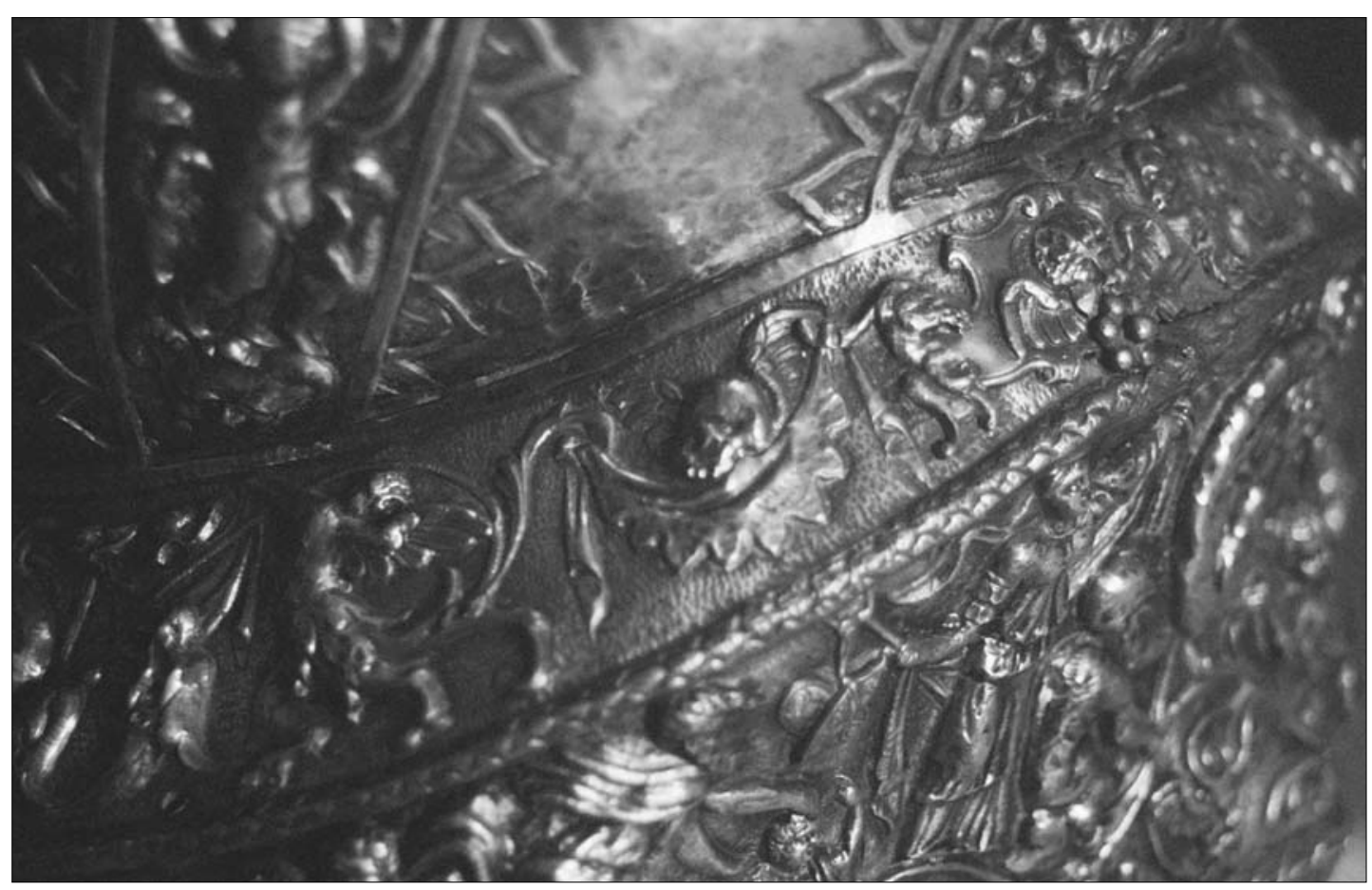

Figura 17. Detalle de la calavera alada.

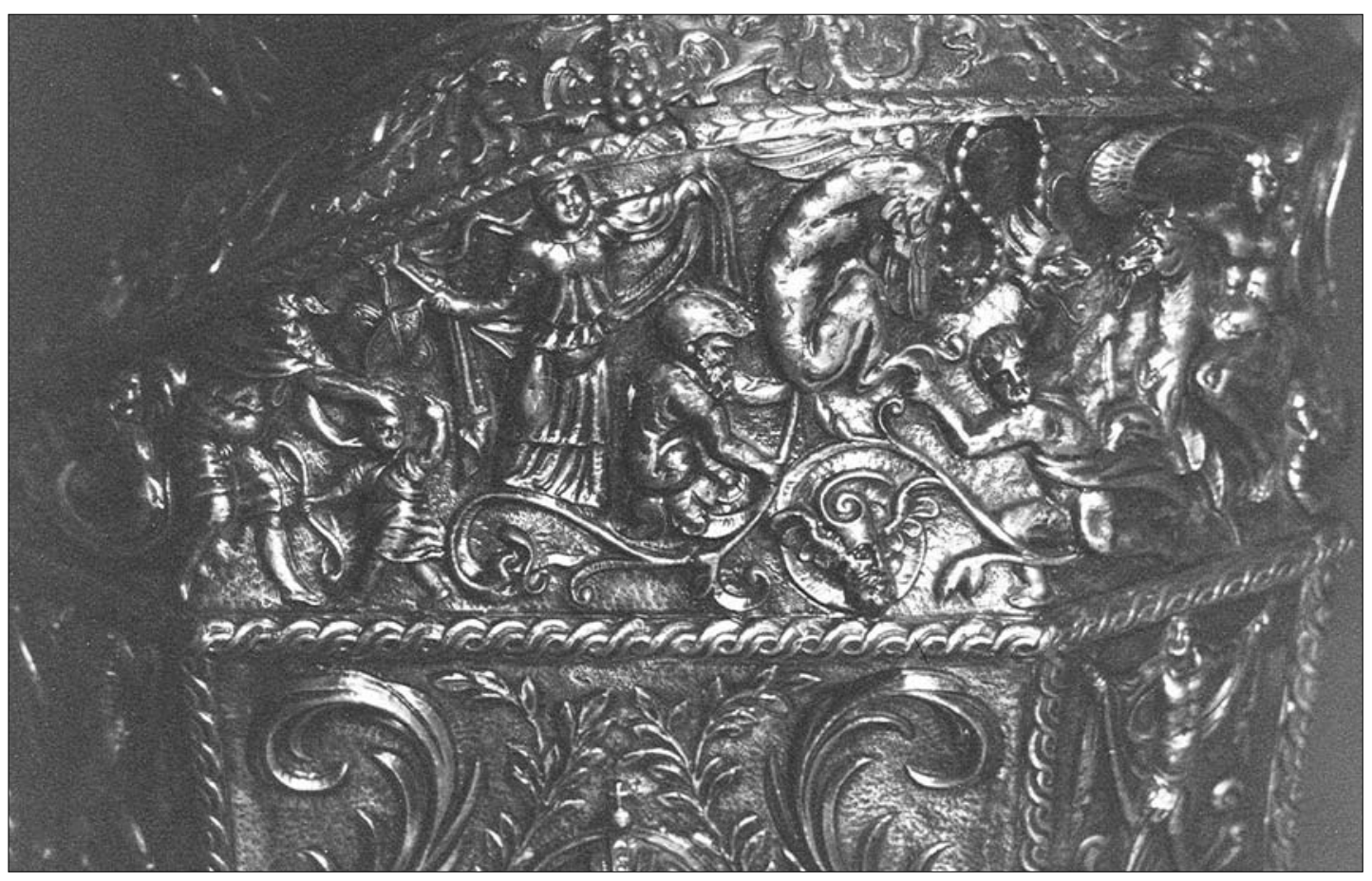

Figura 18. Detalle de la decoración en un lateral de la faldilla de la armadura.

AEA, LXXIX, 316, OCTUBRE-DICIEMBRE, 371-388, 2006, ISSN: 0004-0428 
Con todo este repertorio, Majadas se nos descubre como un gran conocedor de la iconografía contemporánea a Carlos ${ }^{31}$, tanto como para establecer con ella las alusiones convenientes a la grandeza del personaje -identificándose así con un retratador áulico al uso, de la época del Emperador-, y, a la vez, jugar con dicha iconografía y hablarnos de él mismo y de su época. En un momento de "revivals", de usos historicistas de fórmulas antiguas, la obra de Majadas, tanto si la cabeza es del siglo XVI como si es obra suya, es un conjunto de citas del pasado, suficientemente bien recogidas como para que, a su vez, configuren una unidad coherente. Incluso las mismas marcas que lleva la pieza (Fig. 3), repetidas en dos sitios, serían una imitación intencionadamente historicista de las que desde el XVI aparecen en las piezas de plata: supuestamente, o la de la superposición de las letras capitales de la palabra Toledo (a la izquierda en los dos casos) o la del águila bicéfala (a la derecha también en los dos), podrían ser las correspondientes a la marca del contraste o de la localidad de procedencia; y la que siempre aparece en el centro, la del autor, Majadas: sistema bien reproducido en lo formal, aunque parece que no son marcas que consten registradas como oficiales ${ }^{32}$ ni de épocas renacentistas ni más recientes, pero que completan la coherencia mencionada en la propia constatación de la autoría.

Sin embargo, la figura de Majadas se oscurece, a buen seguro, no de forma inocente, al tiempo que se le da relevancia a la de Leoni. Si nos remitimos a los textos en los que este busto aparece mencionado, con una observación cronológica de los mismos, nos encontramos con lo siguiente:

La primera referencia que encontramos está en el Catálogo de Orfebrería, de 192333: en ese momento, la pieza está en manos particulares -Conde de la Revilla-y el autor del catálogo sólo la califica, en general -sin detenerse en la cabeza-, como "reproducción de una armadura de Leoni”. Aunque reconoce el punzón de Majadas, no sabe su ubicación cronológica y, quizás por la fecha de 1575, lo incluye, sin más comentarios, entre los objetos expuestos del siglo XVI.

La segunda referencia la encontramos en el catálogo de la Exposición Internacional de Barcelona de $1929^{34}$. Aquí, la pieza, que continua en manos del mismo dueño, también aparece catalogada entre los objetos expuestos del siglo XVI. Ya no se habla de reproducción sino que, aunque se reconoce el "punzón de Majados (Toledano)", es "armadura de Leoni”.

En tercer lugar, debemos detenernos en otro catálogo, el de la exposición celebrada con motivo del centenario de la muerte del Emperador, en el Museo de Santa Cruz de Toledo, en 1958. En el texto Adquisiciones del Ministerio de Educación y Ciencia a través de la Dirección General de Bellas Artes (1961-1963) se dice, refiriéndose al busto de Carlos: "Exhibido en la Exposición 'Carlos V y su ambiente', en Toledo, aunque no fue incluido en el catálogo" 35. Efectivamente,

${ }^{31}$ En este sentido, debemos exceptuar, del conjunto de lo contemporáneo a Carlos V, la representación de las columnas del Plus Ultra rotas así como su posible referencia a Saavedra Fajardo.

32 Ver: Alejandro Fernández, Rafael Muñoz, Jorge Rabasco: Enciclopedia de la Plata española y Virreinal americana. Edición de los autores. Madrid, 1984. Mismos autores: "Manipulaciones dolosas, confusas y simuladas, en el marcado de la plata". Revista Antiquaria nº 52, 1988.

${ }^{33}$ El busto de Carlos V aparece aquí catalogado con el número 401. Pedro M. de Artínano: Catálogo-Guía de la Exposición de Orfebrería Civil Española. Sociedad Española de Amigos del Arte. Madrid, 1923; dice: "Busto del Emperador Carlos V, de plata dorada repujada; doble punzón de Toledo; punzón de Majadas. Tiene repujada en el pedestal, también de plata, la fecha de 1575. Reproducción de una armadura de Leoni. Expositor: Sr. Conde de la Revilla”, (pág 74).

${ }^{34}$ El Arte en España. Guía del Museo del Palacio Nacional. Exposición Internacional de Barcelona, 1929. Tercera Edición, revisada por don Manuel Gómez Moreno. Barcelona, 1929. El busto aparece catalogado con el número 1338; dice: "busto del Emperador Carlos V, en plata sobredorada y punzón de Majados (Toledano) y armadura de Leoni, con la inscripción: 'CAROLUS QUINTUS IMPERATOR, 1575'. Alto, 0,95 metros. Sr Conde de la Revilla de Madrid”, (pág 444).

35 Adquisiciones del Ministerio de Educación y Ciencia a través de la Dirección General de Bellas Artes (1961-1963). Ministerio de Educación y Ciencia. Dirección General de Bellas Artes. Adquisiciones de Obras de Arte (1961-1963). Servicio de Información, Arqueológico y Etnológica. Madrid, 1968. Pág 142. 
en este catálogo ${ }^{36}$ no se incluye ni se menciona nuestro busto, aunque, sin embargo, tal catálogo sí se siguió mencionando como bibliografía de la pieza. Lo que sí se expuso en 1958 y consta en dicho catálogo, es el busto en plata del Museo Lázaro Galdiano de Madrid, atribuido a Leoni, muy semejante al nuestro (la cabeza es la misma), pero con notables diferencias en la decoración de la armadura y en la peana. Pensamos que, si se expuso éste, no tendría sentido exponer el nuestro, dadas sus semejanzas; además, hay que recordar que, en estos momentos, nuestro busto aún no pertenece al Museo de Santa Cruz, que lo comprará en 1962.

La siguiente referencia la encontramos en el catálogo del pabellón de España, en la Exposición Internacional de New York, en 1964-1965 37. Aquí, en la introducción al apartado artístico, el busto es ya, definitivamente de Leoni: “... Este bello itinerario artístico se redondea con el busto de Leoni dedicado al Emperador Carlos V ..." 38; y, además, se le muestra como obra relevante: en el "Hall de Honor" nos encontramos el "Busto del Emperador Carlos V, de León Leoni" 39, junto con joyas del tesoro de Guarrazar y del Carambolo, etc. Sin embargo, en el estudio detenido de la pieza -y esto sólo se hace con las más señaladas-, aunque en el pie de la foto se indica: "Leoni: Busto de plata de el César, Carlos V"40, en el breve texto, el autor sólo se atreve a insinuar una atribución a Leoni: "Toda la iconografía de las estatuas del Emperador Carlos V se originan en las versiones de León Leoni ... La cabeza de esta escultura, prestada por el Museo del Hospital de Santa Cruz de Toledo, es una casi copia exacta de otra atribuida a Leoni que está guardada en el Museo Lázaro Galdiano de Madrid"41: texto muy ajustado, quizás el mas preciso de todos los que vemos, que contrasta con las imprudentes afirmaciones que le rodean. De todos modos, la desaparición total de Majadas es evidentemente interesada. En paralelo, la atribución a Leoni, cobra fuerza: en un pabellón internacional y en un momento en el que España intenta atraer al turismo y hacerse valer de cara al exterior, la oferta cultural de calidad-recordemos que en este pabellón se exponen obras del románico catalán, de El Greco, Velázquez, Goya, Picasso ...es una baza importante para la cual Leoni es un autor de peso.

La siguiente referencia es el catálogo del Museo de Santa Cruz, hecho por su entonces directora, M. Revuelta ${ }^{42}$, quien sólo menciona la inscripción -incluyendo el año: 1575 - y no menciona ninguna autoría.

En 1968 aparece el texto donde se refieren las adquisiciones de la Dirección General de Bellas Artes entre 1961 y $1963^{43}$. Aquí se nos da noticia de la compra de este busto por Orden Ministerial del 31 de marzo de 1962, para el Museo de Santa Cruz de Toledo. Dicho texto vuelve a mencionar los "punzones de Toledo y Majadas", inscribe a la pieza en el siglo XVI y sólo habla de

\footnotetext{
${ }^{36}$ Carlos V y su ambiente. Exposición homenaje en el IV centenario de su muerte (1558-1958). Ministerio de Educación Nacional. Dirección General de Bellas Artes. Madrid, 1958.

${ }^{37}$ New Official Guide to the Pavilion of Spain, Comisaría General of the Pavilion of Spain for the New York World's Fair, 1964-1965. Madrid, 1965. Los autores de los textos relativos al arte son: José Antonio González y Juan Ramírez de Lucas.

${ }^{38}$ New Official Guide ... op. cit, pág 46.

39 New Official Guide ... op. cit, pág 46

40 New Official Guide ... op. cit, pág 62.

${ }^{41}$ New Official Guide ... op. cit, pág 62. El resto del texto glosa las características y la perfección de los detalles que adornan este busto.

42 Aquí aparece catalogado con el no 457; dice: "Busto del Emperador Carlos V sobre alta peana, vestido con coraza e inscripción: Carlus (sic) Quintus Imperator. 1575. Plata sobredorada en parte ...". M. Revuelta: Museo de Santa Cruz. Toledo. Ministerio de Educación y Ciencia. Dirección General de Bellas Artes. Madrid, 1966. Pág 84.

43 Adquisiciones del Ministerio de Educación y Ciencia a través de la Dirección General de Bellas Artes (1961-1963) . "Redactado bajo la dirección de D. José María de Azcárate, por María Teresa Pérez Higueras, del Servicio Nacional de Información Artística, Arqueológica y Etnológica”.
} 
copia de Leoni ${ }^{44}$, refiriendo esta copia a la armadura cuando, realmente, la similitud no está en ella sino en la cabeza. De todas formas, esta insistencia en la armadura no hace mas que volver a los planteamientos de los primeros textos, los catálogos del año 23 y del año 29.

En 1987 se hace otra edición de la Guía del Museo de Santa Cruz, con la misma autora, M. Revuelta ${ }^{45}$. De forma prudente, sólo dice: "Se tiene por obra de León Leoni y lleva punzón de T y Majadas"46.

En definitiva: habrá que esperar al estudio de Carmen Heredia Moreno y Amelia López-Yarto Elizalde en 199947 para que la figura de este autor, Majadas, comience a poder reivindicarse de forma desprejuiciada y se pueda perfilar una obra que se nos aparece como prometedora.

Recibido: 16-II-2005

Aceptado: 19-IV-2005

44 "Reproduce la parte superior de la armadura del Emperador, que Leoni emplea en sus obras. Está colocado sobre un plinto, también de plata, pero de menor delicadeza en la factura. En la parte posterior del plinto, lleva una inscripción: "Carolus / Quintus / Imperator / 1575'”. Adquisiciones del Ministerio ... . Op. cit, pág 142.

45 M. Revuelta Museo de Santa Cruz de Toledo. I y II. Consejería de Educación y Cultura de la Junta de Comunidades de Castilla La Mancha. Ciudad Real, 1987. Aquí aparece catalogado con el no 268.

46 M. Revuelta Museo de Santa Cruz de Toledo... op. cit, pág 113.

47 C. Heredia y A. López-Yarto: "Los triunfos del Emperador en las Artes del Metal ...”. Op. cit. 